\title{
EFFECTS OF THE EUROPEAN COMMON AGRICULTURAL POLICY ON PRESERVING BIODIVERSITY: FARMLAND BIRDS IN SLOVENIA
}

\author{
Renata Slabe-Erker ${ }^{1}$, Marko Ogorevc ${ }^{2}$, Primož Kmecl ${ }^{3}$, Rok Ciglič ${ }^{4}$
}

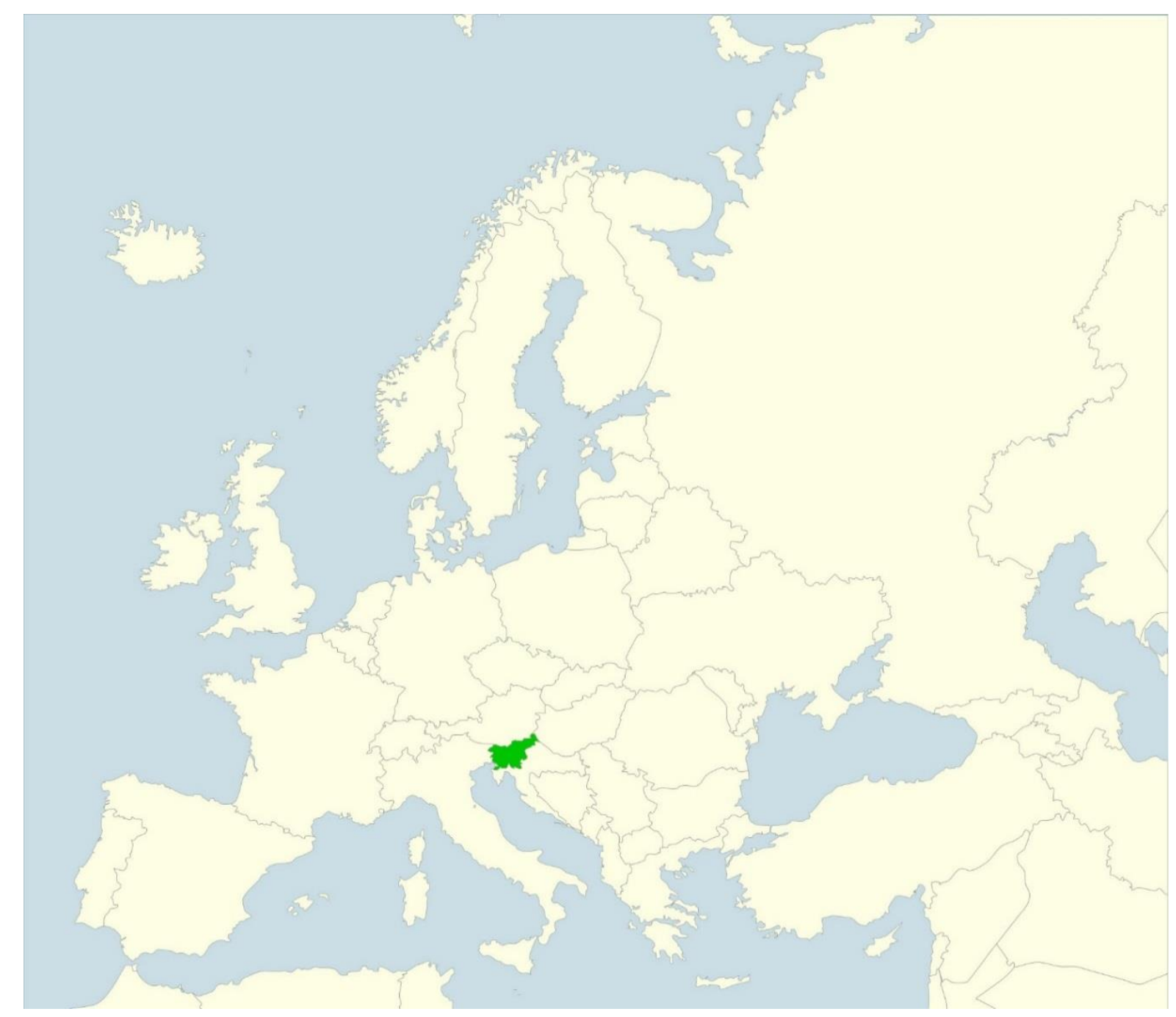

\footnotetext{
${ }^{1}$ Renata Slabe-Erker, PhD, , Institute for Economic Research, Ljubljana, Slovenia, ORCID: 0000-0003-2566-9563, Email: erkerr@ier.si

${ }^{2}$ Marko Ogorevc, PhD., Institute for Economic Research, Ljubljana, Slovenia, ORCID: 0000-0001-9970-3045, Email: ogorevcm@ier.si

3 Primož Kmecl, PhD., DOPPS Birdlife Slovenia, Ljubljana, Slovenia, ORCID: 0000-0003-4247-2922, Email: primoz.kmecl@dopps.si

${ }^{4}$ Rok Ciglič, PhD., Research Centre of the Slovenian Academy of Sciences and Arts, Anton Melik Geographical Institute, Ljubljana, Slovenia, ORCID: 0000-0003-3517-3780, Email: rok.ciglic@zrc-sazu.si
} 


\begin{abstract}
This paper assesses the effects of agricultural payments on changes in farmland bird diversity in Slovenia. Diversity was measured by Shannon index, while the impacts were estimated with the first-difference estimator on panel data for municipalities with and without special protection areas for birds. The effects of agricultural payments on farmland biodiversity require that the balance of financial instruments be taken into account when the agricultural policy is being drafted. The effects of payments in municipalities with and without special protection areas indicate the need to consider the landscape perspective and adapt schemes to landscape type while preparing the national agricultural policy.
\end{abstract}

Keywords: agricultural payments, farmland bird diversity, Shannon index, panel data model, special protection areas

Povzetek: $\vee$ članku ocenjujemo učinke kmetijskih plačil na spremembe $v$ raznovrstnosti ptic kmetijske krajine v Sloveniji. Raznovrstnost je merjena s Shannonovim indeksom, medtem ko so vplivi ocenjeni s cenilko prvih diferenc na panelnih podatkih za občine s Posebnimi območji varstva za ptice in za občine brez teh območij. Učinki kmetijskih plačil na kmetijsko biotsko raznovrstnost kažejo na potrebo, da se pri oblikovanju kmetijske politike poišče ravnovesje med finančnimi instrumenti, in da se pri pripravi nacionalne kmetijske politike, razmisli o krajinski perspektivi ter temu ustrezno prilagodi kmetijske sheme.

\title{
1. Introduction
}

According to Eurostat (2016), $47 \%$ of the total area of Europe is used for agriculture, while nearly $50 \%$ of all European species depend on agricultural habitats (Kristensen, 2003). Within agricultural land, the traditionally managed agricultural areas are particularly important as a habitat for farmland biodiversity (Donald, 2002). However, many farming practices affecting wildlife on farms and adjacent habitats are not very supportive of farmland biodiversity (Tscharntke et al., 2005).

Farmland biodiversity is determined by (i) the diversity of habitats in agricultural landscapes, consisting of intensively used production fields and extensively managed habitats; (ii) the species diversity of wildlife including birds; and (iii) the genetic diversity of crops and species (Herzog et al., 2012). As such, farmland biodiversity is essential for maintaining healthy ecosystems. Yet, in the past few decades, farmland biodiversity has been declining due to agricultural intensification and especially the conversion of grasslands into arable land. For instance, frequently used as a proxy for measuring farmland biodiversity (Chiron, 2013), farmland birds have experienced a decline of 57\% in Europe from 1980 to 2016 (PanEuropean Common Bird Monitoring Scheme, 2018). Therefore, protecting ecosystems and reversing the loss of biodiversity remain important challenges for European agriculture (Matthews et al., 2016).

Birds are often regarded as indicators of the general state of biodiversity of the research area, for both scientific and practical reasons (e.g., Furness \& Kees, 1997; Furness \& Greenwood, 2013, Gregory et al., 2003; Gregory et al., 2004). They are easy to detect, identify and census, live in a widespread habitat, have well-resolved taxonomy, are moderately abundant, have moderate life spans, and are of moderate body size. Besides, birds are at the top of the food chain and thus mirror the accumulated changes in the chain (Gregory et al., 2005). Moreover, the information on breeding bird populations is available throughout Europe (Gamero et al., 2017). However, there are also many problems in using birds as indicators of the entire biodiversity, like migratory habits and a low degree of specialism in some species (Gregory et al., 2005). Based on previous studies and despite mentioned misgivings, in this study we use data on breeding bird population to surrogate the entire biodiversity of the research area and in this way, we do our analysis costeffectively and in a practical manner. 
The European Common Agricultural Policy (CAP) favours agricultural intensification by direct payments aimed at providing basic income support to EU farmers (i.e., the first CAP Pillar). It should, however, be noted that large share of these payments is decoupled from production (implemented in 2005), and farmers must keep their land in good agricultural and environmental condition and meet legislative standards concerning the environment, public health, plant health, and animal health in order to remain eligible to receive this support (cross-compliance conditions) (EC, 2017). The introduction of three greening measures in the first CAP Pillar (Ecological Focus Areas - to safeguard and improve biodiversity on farms, Maintenance of Permanent Grassland required in areas covered by the birds and habitats Directives and Crop Diversification - to improve soil quality) in 2015 also created changes in cross-compliance (Hart et al., 2016). On the other hand, the CAP includes agri-environment measures or payments (i.e., the second CAP Pillar) in an attempt to minimise the negative effects of agriculture practices on biodiversity, as well as on water, soil quality and landscape diversity (Kurz, 2018). Agri-environment payments are made within a respective member state's national Rural Development Programme, which links European and national, local needs, while the states have to provide co-financing.

The wide debate currently underway on CAP reform post-2020 frequently points to environmentally ineffective CAP measures. Researchers (e.g., Matthews et al., 2016; Anania et al., 2015) in particular, criticise the limited environmental benefits of cross-compliance and the greening payment, as well as the scope and conditions of the agri-environment scheme, and seek a way to increase the effectiveness of agri-environmental measures on biodiversity. Moreover, specialists support the idea of clearly distinguishing the global commons and the "quasi-local" commons, where the first should be $100 \%$ financed by the EU budget and the latter jointly managed and co-financed by the EU and the member states. The subject of this study, farmland biodiversity, is considered a pure global public good (non-excludable and nonrivalrous) and therefore, following the proposal, it should be fully financed by the EU (Matthews et al., 2016).

It should be recalled that the CAP receives the biggest share of the EU budget. For illustration, direct payments benefit nearly 7 million farms across the European Union, and in the last ten years, on average, nearly half of farmers' income has come from direct support (EC, 2017). Moreover, agri-environment payments represent 30\% of rural development expenditures from the European Agricultural Guarantee and Guidance Fund (Eurostat, 2012). This indicates the CAP is a complex and well-financed policy that likely has a crucial impact on farmland biodiversity.

Despite resources from EU funds being usually allocated at either national or regional territorial level, Bonfiglio et al. (2015) advocate analysing the ex-post expenditure at a local level. However, when analysing effects of CAP, NUTS 2 regions are usually the aggregation level of choice (Chirion et al., 2013). Our analysis was conducted at LAU 2 level (previously called NUTS 5), which represents the highest level of territorial disaggregation.

So far, studies investigating the impacts of agricultural payments on farmland biodiversity have chiefly focused on aggregated agri-environment payments not broken down to specific groups of agri-environment payments, such as payments for organic farming and payments for nature conservation. Further, they have shown opposing results, inter alia because the focus and methodology vary between the studies. While Batary et al. (2015) observed positive and stabilising effects of agri-environment payments on biodiversity, several studies found no effects or negative effects (e.g., Kleijn \& Sutherland, 2003 and Dicks et al., 2014). Empirical findings are quite controversial, and there is no general agreement on the effectiveness of agri-environment payments. Besides, studies have originated from very few European countries, typically Western Europe (Kleijn \& Sutherland, 2003).

In 2004, Slovenia, Slovakia, Poland, Czech Republic, Hungary, Cyprus, Malta, and the Baltic countries joined the European Union and initiated the agri-environment schemes. Most new member states were included in a recent study by Gamero et al. (2017) who investigated the effects of agri-environment schemes on bird population changes in special protection areas for birds ("SPAs") on the EU scale. They concluded that EU policies generally mitigate the decline of farmland bird populations, but do not reverse them. After a decade or more of agri-environment 
schemes running in new member states, it is an appropriate time to broadly overview the influence of agricultural payments on biodiversity, not limited to SPAs. Therefore, we tested the hypothesis that agri-environmental payments have positive effects on biodiversity, compensating potential negative effects of direct payments.

This study aspires to fill a void in policy evaluation in the region. Unlike previous (forecasting) studies, which modelled the impacts on biodiversity by comparing baseline scenario with various policy scenarios for 2020 (e.g. Overmars et al., 2013; Chiron et al., 2013), this study models the impacts of direct payments (the first CAP Pillar) and agri-environment payments (the second CAP Pillar) in the period 2007-2013 on changes in biodiversity. Moreover, the impacts are assessed separately for municipalities with SPAs and municipalities without SPAs to demonstrate the contribution of the EU Birds Directive to farmland biodiversity.

\section{Study area, Materials and Methods}

We conducted our study using data from Slovenia, a new member state from South-east Europe. The country's small territory $\left(20,273 \mathrm{~km}^{2}\right)$ is characterised by a high diversity of species, ecosystems and landscapes resulting from its location between the Alps, the Dinaric Alps, the Pannonian plains and the Mediterranean (Ciglič \& Perko, 2013). Consequently, public spending on agri-environment measures accounts for the largest share of the country's budget for rural development, and the same applies to Europe (Slabe-Erker et al., 2017).

In this study, we model the impacts of direct payments and agri-environment payments on changes in farmland bird biodiversity. The study is conducted at municipality level (LAU 2, previously called NUTS 5), which represents the most detailed level of territorial disaggregation.

We use the Shannon diversity index as an indicator of the impact of agriculture on biodiversity. The Shannon index is the most popular approach to quantify biodiversity (Shannon \& Weaver, 1949; Chirion, 2010). It has two components - the richness of species and the evenness of abundances of species. It is thus sensitive to the presence of rare species (Smale et al., 2003; Nagendra, 2002).

The Shannon index of farmland bird diversity is defined as follows (Nagendra, 2002):

$$
\text { Shannon index }=-\sum_{i=1}^{N} p_{i} \cdot \ln p_{i}
$$

where $p_{i}$ is the proportion of $i$-th species abundances in total.

We used farmland birds population trends as a proxy for the trends of farmland biodiversity in general (Chirion et al., 2013). We obtained annual data on breeding bird populations from the Slovenian farmland birds census from 2008 to 2013 (Kmecl \& Figelj, 2013). Birds were counted twice yearly during the breeding season. The first count took place from 1 April to 5 May and the second from 6 May to 30 June. The birds were counted during a slow walk (approx. $2 \mathrm{~km} / \mathrm{h}$ ) on $2 \mathrm{~km}$ transects (Bibby et al., 2000), by experienced ornithologists. Altogether, 103 transects were censused. The transects were positioned freely inside $2 \times 2 \mathrm{~km}$ squares (sampling plots). These squares were taken from the grid of the new Slovenian breeding birds atlas (Kmecl \& Figelj, 2013) with the restriction to have more than $40 \%$ of agricultural land use. Again, the selection of these squares was free, distributed unevenly across the agricultural areas of the country (Figure 1). All bird species were counted, but for this analysis, we used 29 species determined as indicator species in Slovenian farmland (Kmecl \& Figelj 2013, see online Appendix, Table A1). The survey unit was a pair, which meant a singing or otherwise observed male, observed female, a group of fledglings or inhabited nest (Koskimies \& Väisänen, 1988). We used the maximum of two yearly counts per species.

In Slovenia, SPAs cover $24.55 \%$ of the total land area, 105 (of 210 ) municipalities are entirely without SPAs (Figure 1). Usually, the SPAs that include farmland have more than one indicator species as a protected species as well as several other farmland species. Some of the SPAs included do not have agriculture as their predominant use (for instance, SPAs with large forest 
and mountainous areas). The sample in this paper includes all SPAs with at least one indicator species of the Slovenian farmland bird index among the protected species according to the Directive on the conservation of wild birds of the European Union (Directive 2009/147/EC; OG RS 2004). Only a few wooded, high-mountain or coastal SPAs with no farmland are excluded. The sample is divided into municipalities with SPAs and municipalities without SPAs.

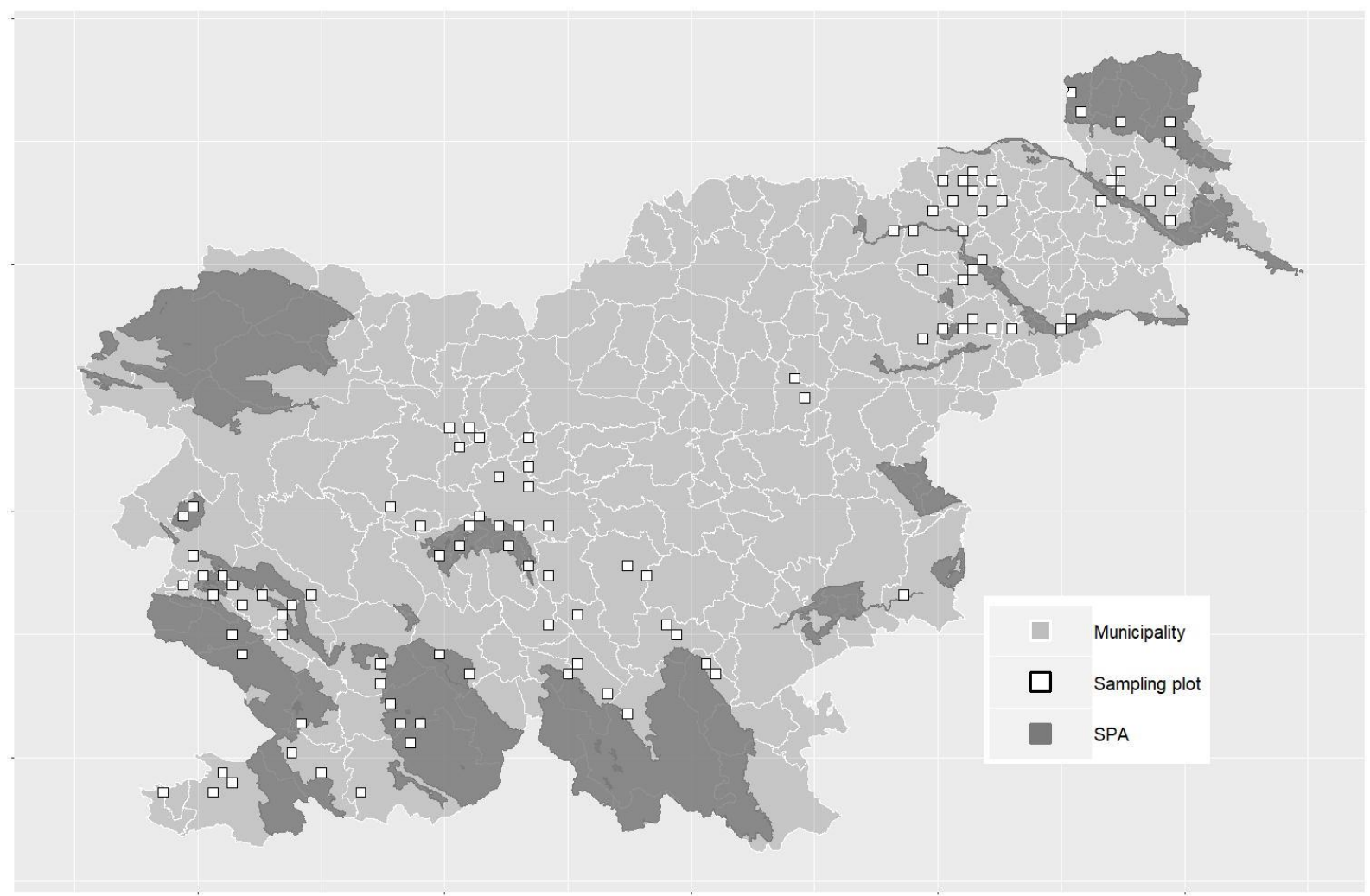

Fig 1. Special protection areas (SPAs) with at least one indicator farmland bird species as a protected species, municipalities and sampling plots of the farmland bird monitoring scheme in Slovenia. Sources: SORS, 2011; SEA, 2016; Kmecl \& Figelj, 2013. Source: own result

Note: Municipalities' borders correspond to the situation in 2010.

Ordinary kriging was used to interpolate abundances on a $1000 \times 1000$ regular grid which covers the entire area of Slovenia. Therefore, the dimension of each cell was set to $163 \mathrm{~m} \times 248 \mathrm{~m}$. Each of the 29 species in each year was interpolated to the regular grid. Kriging values from grid cells were used to obtain average counts for each municipality, including those without monitoring. The average counts were used to calculate the Shannon index of farmland birds.

In order to explain changes in the Shannon index of farmland bird diversity, data on agricultural payments were used. These include direct payments and agri-environment payments. The financial perspective is consistent with the Rural Development Programme and covers the period from 2007 to 2013, while payments were lagging by one year (the first payment in 2008). Effectively, the data on payments, therefore, refer to the implementation in the previous year. Bird abundances were taken from the current year.

To describe the effects of CAP measures on biodiversity, recent evidence suggests also taking specific land uses (e.g., Overmars et al., 2013; Benayas et al., 2007; Dyulgerova et al., 2015) and climate conditions into account (e.g., Jiguet et al., 2010). We use the following land uses according to the CORINE land cover nomenclature as priority farmland habitats for birds: grassland, forest edge, and heterogeneous agricultural areas (agricultural land with areas of natural vegetation - trees, shrubs, and hedgerows) (Table 1). As the land use data is triennial, a linear interpolation was used to fill in the data for missing years. 
Tab 1. Description and source of data for the variables used. Note: ${ }^{1}$ BirdLife Slovenia, ${ }^{2}$ Slovenian Environment Agency, ${ }^{3}$ Slovenian Agency for Agricultural Markets and Rural Development, ${ }^{4}$ Land Use Registry and ${ }^{5}$ Statistical Office of Republic of Slovenia

\begin{tabular}{|l|l|l|l|}
\hline Variable & Definition & Source & Availability \\
\hline Shannon index & Farmland bird species diversity & DOPPS $^{1}$ & $2007-2013$ \\
\hline SPAs & Special Protection Areas under the Birds Directive & SEA $^{2}$ & 2013 \\
\hline Agricultural payments & $\begin{array}{l}\text { Total agricultural payments per hectare of utilised } \\
\text { agricultural area }\end{array}$ & SAAMRD $^{3}$ & $2008-2013$ \\
\hline Forest edge & Length of forest edge in total area $\left(\mathrm{m}^{\prime} / \mathrm{km}^{2}\right)$ & LUR $^{4}$ & $\begin{array}{l}2006,2009,2012, \\
2015\end{array}$ \\
\hline Grassland & Share of grassland areas in total area & LUR $^{4}$ & $\begin{array}{l}2006,2009,2012, \\
2015\end{array}$ \\
\hline $\begin{array}{l}\text { Heterogeneous } \\
\text { agricultural areas }\end{array}$ & $\begin{array}{l}\text { Share of heterogeneous agricultural areas in total } \\
\text { area }\end{array}$ & LUR $^{4}$ & $\begin{array}{l}2006,2009,2012, \\
2015\end{array}$ \\
\hline Temperature & Average May temperature ( $\left.{ }^{\circ} \mathrm{C}\right)$ & SORS $^{5}$ & $2007-2013$ \\
\hline Precipitation & Total monthly precipitation - May $(\mathrm{mm})$ & SORS $^{5}$ & $2007-2013$ \\
\hline
\end{tabular}

A panel data model was estimated to assess the impacts of agricultural policy on farmland bird species diversity measured by the Shannon diversity index at the municipal level:

$$
\begin{gathered}
\Delta S I_{i, t}=\Delta S I_{i, t-1}+\Delta D P_{i, t}+\Delta C S_{i, t}+\Delta A E P 1_{i, t}+\Delta A E P 2_{i, t}+\Delta \text { Forest edge }_{i, t} \\
+\Delta \text { Grassland }_{i, t}+\Delta \text { Heterogenous }_{i, t}+\Delta \text { Precipitation }_{i, t} \\
+\Delta \text { Temperature }_{i, t} \times \text { Precipitation }_{i, t}+e_{i, t}
\end{gathered}
$$

Where $i$ is a municipality index, $t$ is a time index, and $\Delta$ denotes the lagged yearly difference. $S I$ stands for the Shannon diversity index, DP for direct payments, and CS for coupled subsidies (direct payments linked to production). The impacts of agri-environment payments are assessed separately for negative-impact-reducing payments (AEP1) and nature-conservation payments (AEP2). AEP1 includes payments for organic farming, integrated crop production, preservation of crop rotation and greening of arable land, while AEP2 includes, for example, payments for preserving extensive grasslands, preserving grassland habitats, mowing of steep and humpy meadows, meadow orchards, wet meadows, and mountain pastures. To facilitate understanding and for simplification, hereinafter wherever agri-environment payments are written out in full, we refer to them as AEP for organic farming and AEP for nature conservation. The model also takes account of specific land uses and climate conditions. We assumed that bird species diversity is affected by a change in the length of the forest edge (Variable name: Forest edge), a change in grassland area (Grassland), a change in heterogeneous agricultural areas (Heterogeneous), a change in the average May temperature (Temperature) and a change in the total May precipitation (Precipitation). We chose May because for most of the indicator bird species, this is the month of their peak breeding activity and weather conditions in this month have a great impact on their breeding success. The model also considers temporal dynamics by incorporating the lag of the Shannon index.

We used R 3.4.0 (R Development Core Team, 2017) to conduct the statistical analyses. Package "ggplot2" (Wickham, 2009) was used to produce the figures and "stargazer" (Hlavac, 2015) to produce the tables. The panel model was estimated with the first difference estimator using the "plm" (Croissant \& Millo, 2008) package. A test for serial correlation was performed using Wooldridge's (2002) first-difference test for serial correlation in panels. A test for spatial autocorrelation was performed using the Baltagi, Song and Koh (2003) test for the whole sample (without a division into the SPA sample and no-SPA sample). The robustness check was performed to examine how (1) different criteria for the division of municipalities according to the area of SPAs they contain and (2) exclusion of municipalities without direct measurements of bird populations would impact the results. The difference of coefficients was tested using the t- test. 


\section{Results}

The diversity declined in the studied period in the municipalities without SPAs, while this trend is not present in those municipalities with SPAs (Figure 2).

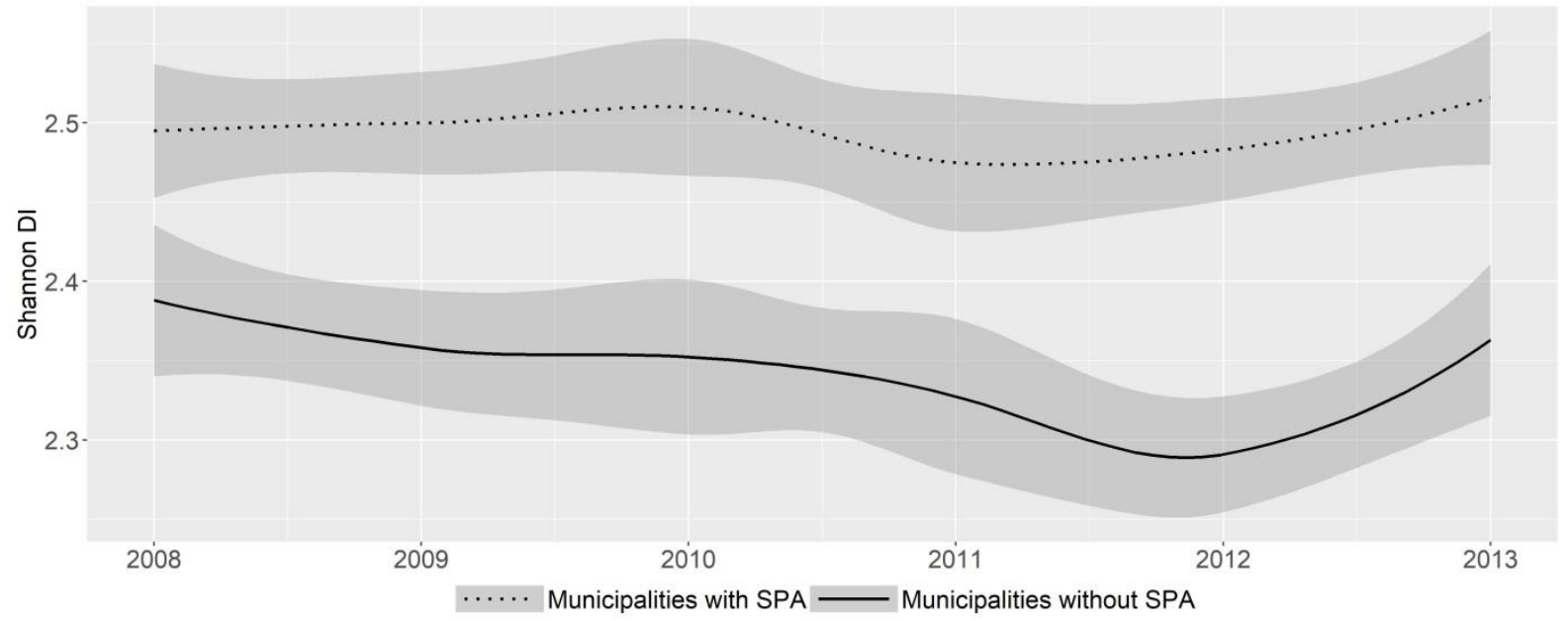

Fig 2. Average annual values of the Shannon diversity index with standard deviations. Source: own result

Descriptive statistics for the Shannon index and predictors used in the model are presented in Table 2 separately for municipalities with SPAs and municipalities without SPAs.

Tab 2. Descriptive statistics.

\begin{tabular}{|c|c|c|c|c|c|c|c|c|}
\hline \multicolumn{5}{|c|}{ Municipalities with SPAs $(n=105, t=6)$} & \multicolumn{4}{|c|}{ Without SPAs $(n=105, t=6)$} \\
\hline Period & & & & & $2008-20$ & & & \\
\hline Variable & Mean & St. dev & Min & Max & Mean & St. dev & Min & $\operatorname{Max}$ \\
\hline \multicolumn{9}{|c|}{ Diversity } \\
\hline Shannon index & 2.495 & 0.225 & 1.763 & 2.922 & 2.342 & 0.257 & 1.049 & 2.900 \\
\hline \multicolumn{9}{|c|}{ Policy variables } \\
\hline Direct Payments (€/ha) & 232.7 & 124.1 & 7.8 & 1648.4 & 237.2 & 84.7 & 18.4 & 678.7 \\
\hline Coupled Subsidies (€/ha) & 25.8 & 17.4 & 0.0 & 122.2 & 41.6 & 20.6 & 0.0 & 107.0 \\
\hline AEP1 - organic farming (€/ha) & 66.5 & 57.2 & 0.0 & 301.6 & 32.1 & 33.0 & 0.0 & 249.0 \\
\hline AEP2 - nature conservation (€/ha) & 15.5 & 13. 6 & 0.0 & 83.7 & 24.3 & 20.1 & 0.0 & 112.3 \\
\hline \multicolumn{9}{|c|}{ Land use variables } \\
\hline Forest edge $\left(\mathrm{m} / \mathrm{km}^{2}\right)$ & 5,501 & 2,010 & 1,756 & 12,080 & 6,127 & 1,558 & 2,081 & 9,973 \\
\hline Heterogeneous & 0.014 & 0.010 & 0.003 & 0.071 & 0.010 & 0.004 & 0.002 & 0.041 \\
\hline Grassland & 0.162 & 0.073 & 0.042 & 0.348 & 0.212 & 0.073 & 0.050 & 0.498 \\
\hline \multicolumn{9}{|c|}{ Climate variables } \\
\hline Average May temperature $\left({ }^{\circ} \mathrm{C}\right)$ & 15.1 & 2.0 & 5.1 & 19.0 & 15.5 & 1.2 & 10.0 & 18.8 \\
\hline Total May precipitation $(\mathrm{mm})$ & 112.2 & 53.1 & 16.9 & 360.8 & 106.4 & 39.7 & 24.5 & 293.7 \\
\hline
\end{tabular}

Note: Amounts are in 2008 constant prices (EUR). 
The average value of the Shannon index, presenting farmland bird species diversity, in the period 2008-2013 was higher in municipalities with SPAs (2.495) than in those without SPAs (2.342). On average, the length of the forest edge was $5,500 \mathrm{~m} / \mathrm{km} 2$ in municipalities with SPAs, and $6,167 \mathrm{~m} / \mathrm{km} 2$ in municipalities without SPAs. Moreover, on average, grassland covered nearly $16 \%$ of the total area in municipalities with SPAs and $21 \%$ of the total area in those municipalities without SPAs, and heterogeneous agricultural areas covered around $1 \%$ of the total area in both types of municipality. The mean May temperature was a little lower and the total May precipitation slightly higher in municipalities with SPAs. These differences are primarily the effect of the SPA "Julijci", which covers $99 \%$ of the Triglav National Park in an Alpine region. Both the mean May temperature of around $15^{\circ} \mathrm{C}$ and slightly more than $100 \mathrm{~mm}$ of May precipitation throughout the country correspond to the area's prevailing moderate continental climate. The t-test confirmed statistically significant differences in all variables, except in direct payments.

In municipalities with SPAs, the total agri-environment payments (AEP1 and AEP2) were higher, and the sum of direct payments and coupled subsidies was lower than in municipalities without SPAs. The AEP for nature conservation (AEP2) are mainly distributed in the Alpine foothills and the Karst region (Figure 3).

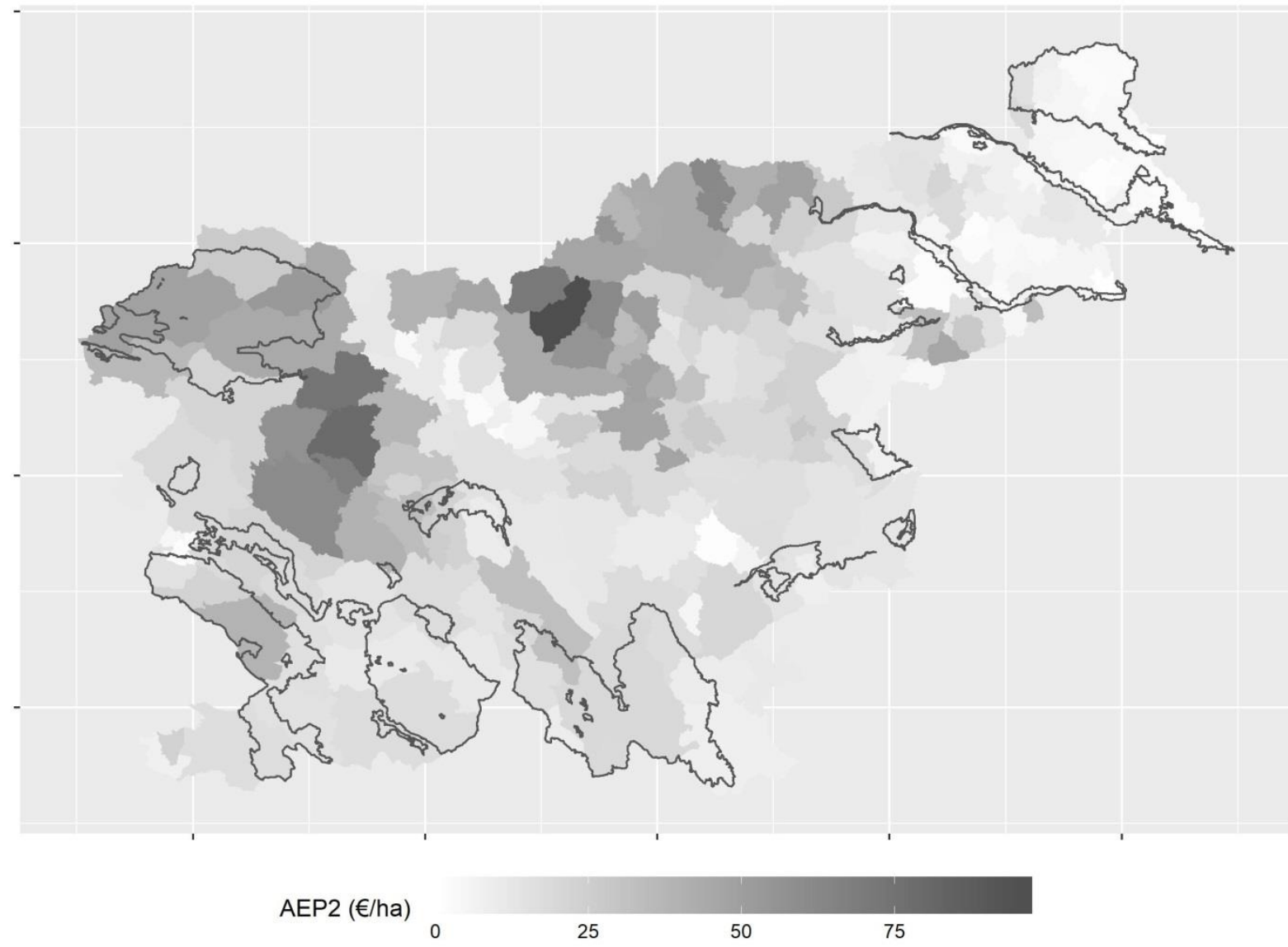

Fig 3. Spatial overlap between average yearly AEP for nature conservation - AEP2 and SPAs with at least one indicator farmland bird species. Source: own result

Direct payments are similar in municipalities with SPAs to those municipalities without SPAs, while coupled subsidies are slightly higher in municipalities without SPAs. AEP1 are higher in municipalities with SPAs while AEP2 are higher in municipalities without SPAs. The trend of AEP1 shows a marked increase in municipalities with SPAs, whereas the trend of AEP2 shows a marked decrease in municipalities without SPAs (Figure 4). Some municipalities did not receive coupled subsidies at all (one in 2010 and 2011 and three in 2013). Further, agri-environment payments were not paid out in all municipalities (one to three municipalities each year). 


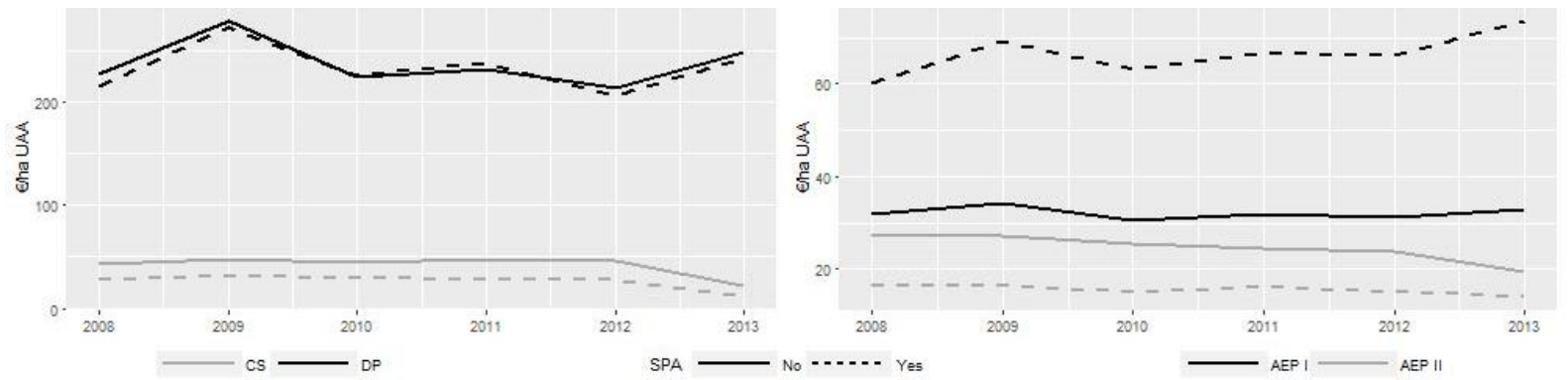

Fig 4. Average annual agricultural payments, 2008-2013. Source: own result

Estimated coefficients for the first-difference model are presented in Table 3 . The impacts on the Shannon diversity index are assessed separately for municipalities with SPAs and those without SPAs.

Tab 3. Regression results of agricultural payments on bird species diversity, first-difference model.

\begin{tabular}{|c|c|c|}
\hline \multicolumn{3}{|l|}{ Shannon DI } \\
\hline & Without SPAs & With SPAs \\
\hline \multirow[t]{2}{*}{ Constant } & $-0.013^{* *}$ & -0.001 \\
\hline & $(-0.007)$ & $(-0.004)$ \\
\hline \multirow[t]{2}{*}{ Direct Payments } & $-0.041^{* * *}$ & $-0.016^{* * *}$ \\
\hline & $(-0.013)$ & $(-0.004)$ \\
\hline \multirow[t]{2}{*}{ Coupled Subsidies } & $-0.052^{*}$ & 0.010 \\
\hline & $(-0.027)$ & $(-0.011)$ \\
\hline \multirow[t]{2}{*}{ Agri-environment payments 1} & $0.054^{* * *}$ & 0.005 \\
\hline & $(-0.021)$ & $(-0.007)$ \\
\hline \multirow[t]{2}{*}{ Agri-environment payments 2} & $0.027^{* *}$ & 0.000 \\
\hline & $(-0.014)$ & $(-0.004)$ \\
\hline \multirow[t]{2}{*}{ Forest Edge } & 0.082 & $0.260^{\star \star \star}$ \\
\hline & $(-0.428)$ & $(-0.088)$ \\
\hline \multirow[t]{2}{*}{ Heterogeneous } & 0.064 & $0.101^{* * *}$ \\
\hline & $(-0.055)$ & $(-0.032)$ \\
\hline \multirow[t]{2}{*}{ Grasslands } & $0.717^{* \star \star}$ & 0.069 \\
\hline & $(-0.268)$ & $(-0.091)$ \\
\hline \multirow[t]{2}{*}{ Precipitation } & $-0.080^{*}$ & $-0.056^{\star * *}$ \\
\hline & $(-0.042)$ & $(-0.020)$ \\
\hline \multirow[t]{2}{*}{ Temp $\times$ Precipitation } & $0.036^{* *}$ & $0.029^{* * *}$ \\
\hline & $(-0.016)$ & $(-0.008)$ \\
\hline \multirow[t]{2}{*}{ Shannon $_{\mathrm{t}-1}$} & $-0.567^{* * *}$ & $-0.343^{* * *}$ \\
\hline & $(-0.087)$ & $(-0.039)$ \\
\hline Serial correlation test & $6.704^{* *}$ & $28.006^{* * *}$ \\
\hline Spatial autocorrelation test & 1.460 & \\
\hline $\mathrm{R}^{2}$ & 0.361 & 0.204 \\
\hline Adjusted R2 & 0.345 & 0.185 \\
\hline \multirow[t]{2}{*}{ F Statistic } & $23.065^{\star * *}$ & $10.512^{* * *}$ \\
\hline & $(\mathrm{df}=10 ; 409)$ & $(\mathrm{df}=10 ; 409)$ \\
\hline $\mathrm{n}$ (municipalities) & 105 & 105 \\
\hline Municipalities x yearly changes of SI & 420 & 420 \\
\hline
\end{tabular}

Note: Significance levels: ${ }^{*}<0.1 ;{ }^{* *}<0.05 ;{ }^{* \star *}<0.01$; serial correlation consistent standard errors in brackets. 
The first-difference test for serial correlation was statistically significant in both types of municipalities; hence, we used serial correlation consistent standard errors, while the test for spatial autocorrelation was not statistically significant at 0.1 . $R$ square was moderate in the case of municipalities without SPAs and lower in the case of municipalities with SPAs. On average and with other predictors constant, the Shannon index is decreasing by $0.013 \%$ per year in municipalities without SPAs, while it is not decreasing in municipalities with SPAs. Effects of agricultural payments are mainly observed in municipalities without SPAs. An increase in direct payments by $1 \%$ is followed by a $0.041 \%$ drop in the Shannon index in the next year. In addition, the increase of coupled subsidies by $1 \%$ is followed by a $0.052 \%$ decrease in the Shannon index in the following year.

In contrast to municipalities without SPAs, there is no statistically significant correlation between the Shannon index and coupled subsidies in municipalities with SPAs, whereas direct payments have a negative effect on diversity regardless of SPAs. A $1 \%$ rise in direct payments is associated with a $0.016 \%$ drop in the Shannon index in the next year. The results reveal a statistically significant connection between the Shannon index and agri-environment payments only in municipalities without SPAs. Higher AEP for organic farming increase the Shannon index (0.054) and, similarly, higher AEP for nature conservation slightly increase the Shannon index (0.027). On the other hand, there is no statistically significant connection between the Shannon index and agri-environment payments in municipalities with SPAs.

We found no statistically significant connection between specific land uses, i.e., forest edge, and heterogeneous agricultural areas, in municipalities without SPAs, while the effect of these land uses is present in municipalities with SPAs. An increase of the forest edge and heterogeneous agricultural areas by $1 \%$ is followed by an increase in the Shannon index of $0.260 \%$ and $0.101 \%$, respectively, in municipalities with SPAs. By contrast, an increase of grasslands by $1 \%$ is followed by an increase in the Shannon index of $0.717 \%$ in municipalities without SPAs, while an increase in this land use has no statistically significant effect in municipalities with SPAs.

The effect of precipitation is statistically significant in both types of municipalities. However, the effect of precipitation on diversity is non-linear and different for different values of temperature. Higher precipitation reduces the average temperature. The effect on bird diversity is most beneficial when both average temperature and precipitation are high.

To demonstrate how different criteria for the division of municipalities impacts results, regression coefficients were estimated at different cut-off points for shares of SPA in the total municipality area. Regression coefficients of agricultural payments remain stable when the share of SPA in municipality increases. Division of municipalities at different shares of SPA does not significantly impact the results of the regression model when the share of SPA is larger than 0 (Figure 5).

To examine how the use of interpolation of bird populations impacts results, regression coefficients were estimated on a subsample of municipalities with direct measurements of bird populations ( $40 \%$ of municipalities contain censused transects) and compared to the whole sample. A $1 \%$ rise in coupled subsidies is associated with additional $0.027 \%$ drop in the Shannon index in the following year, while higher AEP for organic farming increase the Shannon index additionally by $0.02 \%$. Differences of coefficients between this model and the model with all municipalities were not statistically significant for direct payments and AEP for natureconservation. The impacts of agricultural payments do not change direction when only a subsample of municipalities is analysed, and they merely intensify in the case of coupled subsidies and AEP for organic farming. These differences are highlighted in Figure 5. 


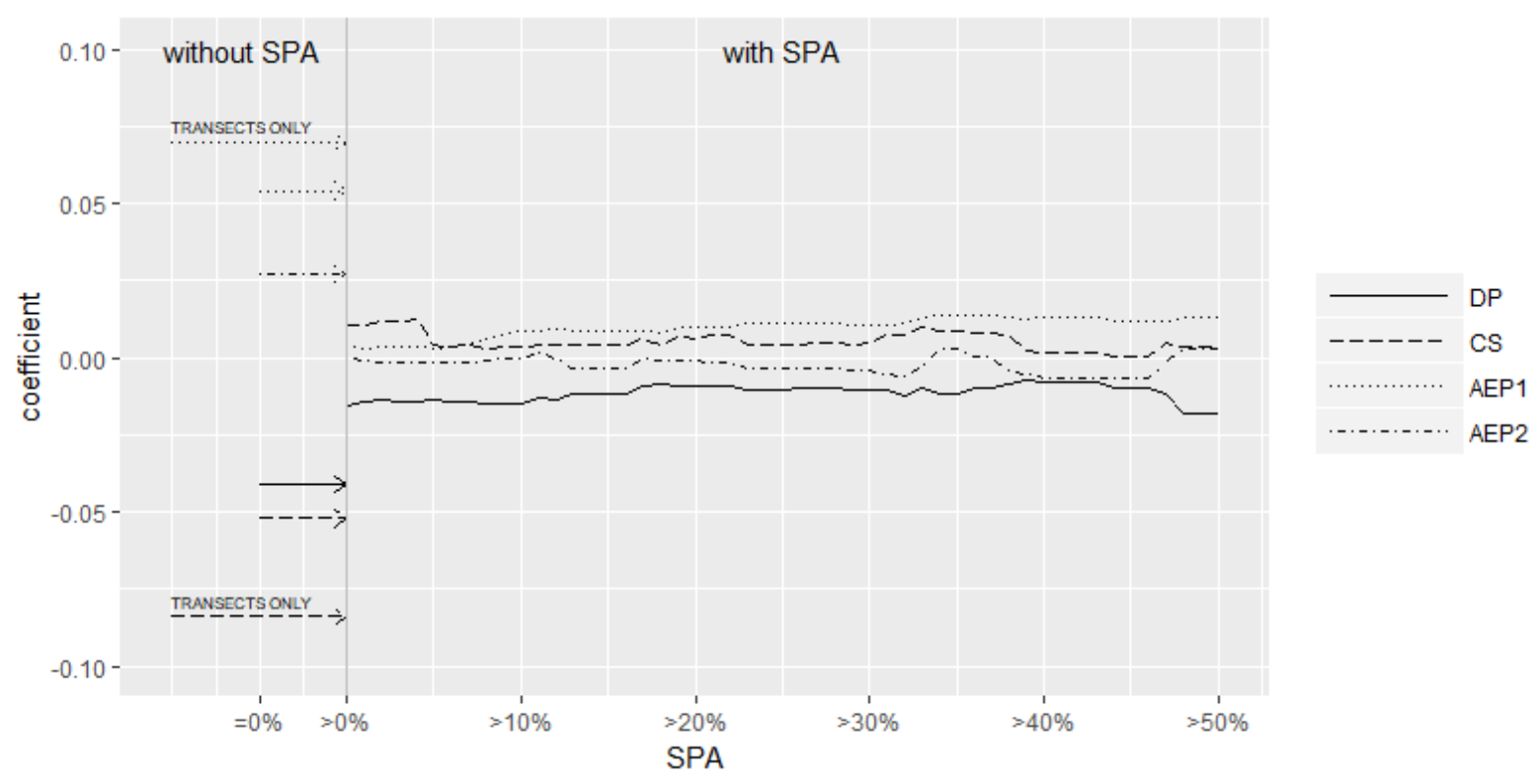

Fig 5. Regression coefficients at different shares of SPA in municipalities. Source: own result

\section{Discussion and conclusion}

This study was designed to determine the effects of the CAP first Pillar measures, i.e., direct payments including coupled subsidies and CAP second Pillar measures, i.e., AEP, on farmland bird diversity in Slovenia in the period 2008-2013. Different payments had different effects (positive or negative). Therefore, the balance of different financial instruments must be given due attention when the policy is being drafted. Since the relationships were significant for municipalities without SPAs, but not for municipalities with SPAs, we must differentiate these two groups.

As Chirion et al. (2013) suggested, the effectiveness of the CAP on biodiversity should be tested on smaller spatial levels, such as regions, and the best policies at the sublevels combined to create a national plan. Our study at municipality level demonstrates that in designing agricultural policy in Slovenia, it would be reasonable to develop measures separately for SPAs. Not taking SPAs into account is likely one source of the contradictory results of some studies on the regional level (Kleijn \& Sutherland, 2003; Dicks et al., 2014). Moreover, SPAs are typically linked to special landscape (extensive agricultural land-use and landscape mosaic structure) (Hrustel Majcen et al., 2010), therefore our results are also in line with Tscharntke et al. (2005) who claim that financial support to farmers should consider the landscape perspective and better adapt schemes to the landscape type.

The second major finding of this study is that AEP are potentially important for preserving bird diversity. In municipalities without SPAs, AEP increase bird diversity, but direct payments and coupled subsidies have a bigger opposing effect. Bird diversity is still declining in these municipalities. According to Batary et al. (2015), AEP can be effective for conserving farmland wildlife, but are expensive and need to be carefully designed and targeted. In addition, as part of the CAP reform post-2020, it is recommended that payments be targeted to specific objectives with a clear orientation on results (Matthews et al., 2016). This means shifting from the 'paymentobligation' policy to a contractual policy that defines objectives and results. Further, the Swiss idea that farmers with more land would find it easier to set land aside for biodiversity priority areas is appealing.

Even though the farmland bird diversity fares much better in the municipalities with SPAs, the AEP in these municipalities apparently do not function (we did not notice any effect in our study) and are therefore unable to compensate for the farmland bird diversity loss elsewhere. The overall farmland bird index for the whole country for the period 2008-2013 was thus just 78.4 the starting value in 2008 was 100, which means a drop of $21.6 \%$ (Kmecl \& Figelj, 2013). We assume there are three reasons for the insignificant impact of AEP in municipalities with SPAs: 
firstly, municipalities with SPAs have less agricultural land use, and the effects of both direct payments and AEP are less pronounced. Secondly, the current study implies a problem of low AEP aimed at nature conservation compared to AEP for organic farming and direct payments. Lastly, funding is poorly targeted concerning biodiversity conservation needs. Butler et al. (2010) also pointed this issue out, and similarly, Tscharntke et al. (2005) indicated that agri-environment schemes for complex landscapes, such as those including SPAs, are not sufficiently targeted to the needs of the species they aim to protect. SPAs are species oriented measure, and to fulfil their conservation goals, AEP should contribute to the goals of individual protected species through tailor-made payments. Some species can serve as umbrella species since through the improvement of their habitat we can contribute to the conservation of other conservatively important species.

However, on average, biodiversity is not declining in these municipalities, probably due to the contribution made by the SPAs. Gamero et al. (2017) also found that SPAs affected protecting farmland bird species and generally fulfilling the main role they were designed for. Even though on average, the farmland bird diversity is not declining, the negative effect of the direct payments in municipalities with SPAs and simultaneously more farmland is still present, as clearly seen in the model. Therefore, we believe steps should be taken to promote measures for nature conservation in municipalities with SPAs and to reconsider whether farmers are being paid enough for their provision of nature conservation services. Further, for both types of municipalities, our results support efforts to improve the AE scheme and the use of targeted payments coupled with specific objectives with a clear orientation to results.

In addition, our study shows that direct payments decrease bird diversity not only in municipalities with SPAs but also in those without SPAs. The finding agrees with the study of Reger (2009), proving that direct payments lead to low values of all habitat diversity indices. However, there is evidence that abolishing or reducing direct payments would in some areas lead to land abandonment and a reduction of available habitats for most farmland species, and to the loss of farmland bird diversity (e.g., Brady et al., 2012, Wretenberg et al., 2006). Direct payments are perhaps good for preventing the abandoning of land and hence a radical drop in diversity but are insufficient for maintaining the historical diversity. As our model does not include areas under abandonment nor the level of intensification, future research should focus on those. We would also like to stress that we focused our research on a wider, municipality level and that different landscape scales might give different results and further insight into the impact of CAP on biodiversity.

More information on the CAP's impacts on biodiversity and nature conservation, in general, should help us establish greater accuracy on this matter. If the debate is to move forward, a better understanding of the close interrelationship of agriculture and the environment must be developed.

Although our paper resolves some of the theoretical and methodological issues of existing studies, it still has certain limitations. The municipality level might not be most suitable for analysing biodiversity, because municipalities vary a lot in size and could be very heterogeneous. However, when analysing effects of policy (CAP), NUTS 2 regions are usually the aggregation level of choice. Next, our study focuses on bird population to surrogate the entire biodiversity of the research area. Although this is established approach in recent studies, further research should consider its limitations and try to create a more robust indicator for biodiversity that can also be used for studying the effects of agricultural and environmental policies on biodiversity.

\section{Acknowledgments}

This work was supported by the Ministry of Agriculture, Forestry and Food (Grant No. 2330- 16000178 and public procurement contract No. 2330-16-310015). The authors also acknowledge the financial support from the Slovenian Research Agency (research core funding No. P5-0096 and No. P6-0101). Besides, we want to thank the volunteers of DOPPS BirdLife Slovenia for the help with the gathering of the bird monitoring data. 
[1] Baltagi, B. H., Song, S. H., \& Koh, W. (2003). Testing panel data regression models with spatial error correlation. Journal of Econometrics 117, 123-150. DOI: 10.1016/S03044076(03)00120-9.

[2] Batáry, P., Dicks, L. V., Kleijn, D. \& Sutherland, W. J. (2015). The role of agri-environment schemes in conservation and environmental management. Conservation Biology 29(4), 1006-1016. DOI: 10.1111/cobi.12536.

[3] Benayas, J. R., Martins, A., Nicolau, J. M. \& Schulz, J. J. (2007). Abandonment of agricultural land: an overview of drivers and consequences. $C A B$ reviews: perspectives in agriculture, veterinary science, nutrition and natural resources 2(57), 1-14. DOI: 10.1079/PAVSNNR20072057.

[4] Bibby, C. J., Burgess, N. D., Hill, D. A. \& Mustoe, S. (2000). Bird Census Techniques, $2^{\text {nd }}$ ed. London: Academic Press.

[5] Brady, M., Sahrbacher, C., Kellermann, K. \& Happe, K. (2012). An agent-based approach to modelling impacts of agricultural policy on land use, biodiversity and ecosystem services. Landscape Ecology 27(9), 1363-1381. DOI: 10.1007/s10980-012-9787-3.

[6] Bonfiglio, A., Camaioni, B., Coderoni, S., Esposti, R., Pagliacci, F. \& Sotte, F. (2015). Distribution and re-distribution of CAP expenditure throughout the EU. In Agriculture in an interconnected World. Milwaukee: International Association of Agricultural Economists.

[7] Butler, S. J., Boccacciob, L., Gregoryc, R. D., Vorisekd, P. \& Norrisa, K. Q. (2010). Quantifying the impact of land-use change to European farmland bird populations. Agriculture, Ecosystems and Environment 137(3-4), 348-357. DOI: 10.1016/j.agee.2010.03.005.

[8] Chiron, F., Filippi-Codaccioni, O., Jiguet, F. \& Devictor, V. (2010). Effects of non-cropped landscape diversity on spatial dynamics of farmland birds in intensive farming systems. Biological Conservation 143(11), 2609-2616. DOI: 10.1016/j.biocon.2010.07.003.

[9] Chirion, F., Princé, K., Paracchini, M. L., Bulgheroni, C. \& Jiguet, F. (2013). Forecasting the potential impacts of CAP-associated land use changes on farmland birds at the national level. Agriculture, Ecosystems \& Environment 176, 17-23. DOI: 10.1016/j.agee.2013.05.018.

[10] Ciglič, R. \& Perko, D. (2013). Europe's landscape hotspots. Acta Geographica Slovenica 55(2): 235-270. DOI: 10.3986/AGS53106.

[11] Croissant, Y. \& Millo, G. (2008). Panel data econometrics in R: The plm package. Journal of Statistical Software, 27(2), 1-43. DOI: 10.18637/jss.v027.i02.

[12] Dicks, L. V., Ashpole, J. E., Dänhardt, J., James, K., Jönsson, A. M., Randall, N., Showler, D. A., Smith, R. K., Turpie, S., Williams, D. \& Sutherland, W. J. (2014). Farmland Conservation: Evidence for the effects of interventions in northern and western Europe (Vol. 3). Exeter: Pelagic Publishing Ltd.

[13] Donald, P. F., Green, R. E. \& Heath, M. F. (2001). Agricultural intensification and the collapse of Europe's farmland bird populations. Proceedings of the Royal Society of London B: Biological Sciences 268(1462), 25-29. DOI: 10.1098/rspb.2000.1325.

[14] Dyulgerova, S., Gramatikov, M., Pedashenko, H., Vassilev, K., Kati, V. \& Nikolov, S. C. (2015). Farmland birds and agricultural land abandonment: evidences from Bulgaria. Acta Zoologica Bulgarica 67(2), 223-234.

[15] Furness, R. W. \& Camphuysen, K. (1997). Seabirds as monitors of the marine environment. ICES Journal of Marine Science, 54(4), 726-737.

DOI: 10.1006/jmsc.1997.0243. 
[16] Furness, R. W. \& Greenwood, J. J., eds. (2013). Birds as monitors of environmental change. Berlin: Springer Science \& Business Media. DOI: 10.1007/978-94-015-1322-7.

[17] Gamero, A., Brotons, L., Brunner, A., Foppen, R., Fornasari, L., Gregory, R. D., Herrando, S., Hořák, D., Jiguet, F., Kmecl, P. \& Lehikoinen, A. (2017). Tracking Progress Towards EU Biodiversity Strategy Targets: EU Policy Effects in Preserving its Common Farmland Birds. Conservation Letters 10(4), 395-402. DOI: 10.1111/conl.12292.

[18] Gregory, R. D., Noble, D., Field, R., Marchant, J., Raven, M. \& Gibbons, D. W. (2003). Using birds as indicators of biodiversity. Ornis Hungarica, 12(13), 11-24.

[19] Gregory, R. D., Noble, D. \& Custance, J. (2004). The state of play of farmland birds: population trends and conservation status of lowland farmland birds in the United Kingdom. Ibis 146, 1-13. DOI: 10.1111/j.1474-919X.2004.00358.x.

[20] Gregory, R. D., Van Strien, A., Vorisek, P., Gmelig Meyling, A. W., Noble, D. G., Foppen, R. P. \& Gibbons, D. W. (2005). Developing indicators for European birds. Philosophical Transactions of the Royal Society B: Biological Sciences, 360(1454), 269-288. DOI: $10.1098 /$ rstb.2004.1602.

[21] Hart, K., Buckwell, A. \& Baldock, D. (2016). Learning the lessons of the Greening of the CAP [research report]. Worcester: UK Statutory Conservation, Countryside and Environment Agencies.

[22] Herzog, F., Balazs, K., Dennis, P., Friedel, J. K., Jeanneret, P., Geijzendorffer, I., Kainz, M. \& Pointereau, P. (2012). Biodiversity indicators for European farming systems. Zürich: Forschungsanstalt Agroscope.

[23] Hrustel Majcen, M., Šušmej, T., Tisu, M. (2010). Kmetijstvo na območjih Natura 2000 Ljubljana: Ministry of Agriculture, Forestry and Food.

[24] Jiguet, F., Gregory, R. D., Devictor, V., Green, R. E., Vořišek, P., Van Strien, A. \& Couvet, D. (2010). Population trends of European common birds are predicted by characteristics of their climatic niche. Global Change Biology, 16(2), 497-505. DOI: 10.1111/j.13652486.2009.01963.x.

[25] Kleijn, D. \& Sutherland, W. J. (2003). How effective are European agri-environment schemes in conserving and promoting biodiversity? Journal of Applied Ecology, 40(6), 947-969. DOI: 10.1111/j.1365-2664.2003.00868.x.

[26] Kmecl, P. \& Figelj, J. (2013). Monitoring splošno razširjenih vrst ptic za določitev slovenskega indeksa ptic kmetijske krajine - poročilo za leto 2013. Ljubljana. Slovenian Bird Observation and Study Society.

[27] Koskimies, P. \& Väisänen, R. A. (1988). Monitoring Bird Populations. A Manual of Methods Applied in Finland. Helsinki: University of Helsinki.

[28] Kristensen, P. (2003). EEA core set of indicators: revised version. [Technical report]. Copenhagen: European Environmental Agency.

[29] Kurz, P. (2018). Between Smallholder Traditions and "Ecological Modernisation"-Agricultural Transformation, Landscape Change and the Cap in Austria 1995-2015. European Countryside 10(1), 158-179. DOI: 10.2478/euco-2018-0010.

[30] Matthews, A., Mahé, L. P., Bureau, J. C., Dax, T. \& Copus, A. (2016). Research for Agri Committee - CAP Reform Post-2020 - Challenges in Agriculture. Brussels: Committee for Agriculture and Rural development.

[31] Nagendra, H. (2002). Opposite trends in response for the Shannon and Simpson indices of landscape diversity. Applied Geography 22(2). 175-186. DOI: 10.1016/S01436228(02)00002-4.

[32] Overmars, K. P., Helming, J., van Zeijts, H., Jansson, T. \& Terluin, I. (2013). A modelling approach for the assessment of the effects of Common Agricultural Policy measures on 
farmland biodiversity in the EU27. Journal of Environmental Management 126, 132-141. DOI: 10.1016/j.jenvman.2013.04.008.

[33] Reger, B., Sheridan, P., Simmering, D., Otte, A. \& Waldhardt, R. (2009). Potential effects of direct transfer payments on farmland habitat diversity in a marginal European landscape. Environmental Management 43(6), 1026-1038. DOI: 10.1007/s00267-008-9270-8.

[34] Shannon, C. E. \& Weaver, W. (1949). The Mathematical Theory of Communication. Urbana and Chicago: University of Illinois Press.

[35] Slabe-Erker, R., Bartolj, T., Ogorevc, M., Kavaš, D. \& Koman, K. (2017). The impacts of agricultural payments on groundwater quality: Spatial analysis on the case of Slovenia. Ecological Indicators 73, 338-344. DOI: 10.1016/j.ecolind.2016.09.048.

[36] Smale, M., Meng, E., Brennan, J. P. \& Hu, R. (2003). Determinants of spatial diversity in modern wheat: examples from Australia and China. Agricultural Economics 28(1), 13-26. DOI: 10.1016/S0169-5150(02)00067-1.

[37] Swinnen J., ed. (2015). The Political Economy of the 2014-2020 Common Agricultural Policy. Brussel: CEPS.

[38] Tscharntke, T., Klein, A. M., Kruess, A. \& Thies, C. (2005). Landscape perspectives on agricultural intensification and biodiversity - ecosystem service management. Ecology Letters 8(8): 857-874. DOI: 10.1111/j.1461-0248.2005.00782.x.

[39] Wickham, H. (2009). ggplot2: Elegant Graphics for Data Analysis. New York: SpringerVerlag.

[40] Wooldridge, J. (2002). Econometric Analysis of Cross-Section and Panel Data. Cambridge (MA): MIT press.

[41] Wretenberg, J., Pärt, T. \& Berg, Ĺ. (2010). Changes in local species richness of farmland birds in relation to land-use changes and landscape structure. Biological Conservation 143(2) 375-381. DOI: 10.1016/j.biocon.2009.11.001.

\section{Other sources}

[42] European Commission (2017) CAP Explained. Direct Payments for Farmers 2015-2020. http://ec.europa.eu/agriculture/sites/agriculture/files/direct-support/direct-

payments/docs/direct-payments-schemes_en.pdf, accessed 27.3.2017.

[43] Eurostat, 2012, 2016. http://ec.europa.eu/eurostat.

[44] Hlavac, M. (2015). Stargazer: Well-Formatted Regression and Summary Statistics Tables. $\mathrm{R}$ package version 5.2. http://CRAN.R-project.org/package=stargazer.

[45] LUR - Land use registry. 2015. Zbirka geostatističnih podatkov [Collection of geostatistic data, dataset]. Accessed February 7, 2016.

[46] OG RS. (2004). Decree on special protection areas (Natura 2000 areas). Official Gazette of the Republic of Slovenia no. 49/2004.

http://www.pisrs.si/Pis.web/pregledPredpisa?id=URED283. Accessed 31 Dec 2017 (In Slovene).

[47] PanEuropean Common Bird Monitoring Scheme (2018). https://pecbms.info. Accessed 7 August 2019.

[48] R Core Team (2017). R: A language and environment for statistical computing. R Foundation for Statistical Computing, Vienna, Austria. https://www.R-project.org/.

[49] SAAMRD - Slovenian Agency for Agricultural Markets and Rural Development: Agricultural payments. 2014 [dataset]. Accessed May 8, 2015. 
[50] SEA - Slovenian Environment Agency (2016). Geoportal ARSO [dataset] Accessed February 7, 2016.

[51] SORS - Statistical Office of Republic of Slovenia. Climate indicators, 1981-2014 [dataset]. Accessed February 7, 2016. 


\section{Appendix}

\begin{tabular}{|c|c|c|c|}
\hline Species & & Index ${ }^{*}$ & $\mathbf{S E}^{*}$ \\
\hline Kestrel & Falco tinnunculus & 123.1 & 17.1 \\
\hline Lapwing & Vanellus vanellus & 68.9 & 18.3 \\
\hline Stock Dove & Columba oenas & 104.9 & 41.7 \\
\hline Woodpigeon & Columba palumbus & 124.0 & 18.3 \\
\hline Turtle Dove & Streptopelia turtur & 46.0 & 14.4 \\
\hline Hoopoe & Upupa epops & 46.5 & 16.1 \\
\hline Wryneck & Jynx torquilla & 82.4 & 13.8 \\
\hline Green & Picus viridis & 88.5 & 16.2 \\
\hline Crested Lark & Galerida cristata & 93.1 & 22.2 \\
\hline Woodlark & Lullula arborea & 70.9 & 10.9 \\
\hline Skylark & Alauda arvensis & 64.7 & 6.5 \\
\hline Swallow & Hirundo rustica & 122.9 & 13.1 \\
\hline Tree Pipit & Anthus trivialis & 80.1 & 15.2 \\
\hline Yellow Wagtail & Motacilla flava & 160.3 & 38.7 \\
\hline Nightingale & Luscinia megarhynchos & 106.0 & 14.2 \\
\hline Redstart & Phoenicurus & 143.3 & 34.2 \\
\hline Whinchat & Saxicola rubetra & 69.5 & 15.4 \\
\hline Stonechat & Saxicola torquatus & 51.5 & 7.2 \\
\hline Marsh Warbler & Acrocephalus palustris & 70.3 & 12.0 \\
\hline Whitethroat & Sylvia communis & 71.4 & 12.9 \\
\hline Red-backed & Lanius collurio & 74.3 & 10.2 \\
\hline Starling & Sturnus vulgaris & 76.4 & 9.7 \\
\hline Tree Sparrow & Passer montanus & 83.7 & 8.4 \\
\hline Serin & Serinus serinus & 68.4 & 7.1 \\
\hline Goldfinch & Carduelis carduelis & 72.6 & 9.8 \\
\hline Linnet & Carduelis cannabina & 41.8 & 11.6 \\
\hline Yellow Bunting & Emberiza citrinella & 72.5 & 6.5 \\
\hline Cirl Bunting & Emberiza cirlus & 74.0 & 12.3 \\
\hline Corn Bunting & Emberiza calandra & 50.8 & 11.0 \\
\hline
\end{tabular}

${ }^{*}$ Kmecl \& Figelj (2013)

Table A1: Indicator bird species for Slovenian farmland and their indices and standard errors for the period 2008-2013 